\title{
Periosteal Cell
}

National Cancer Institute

\section{Source}

National Cancer Institute. Periosteal Cell. NCI Thesaurus. Code C33305.

A cell of the loose cellular inner layer of the periosteal tissue in the intramembranous ossification of bone 